Журнал«Герспективитаінновації науки

(Серія «Гедагогіка», Серія «Гиихологія»), Серія«Медицина»

№5(5) 2021

УДК 378.112

https://doi.org/10.52058/2786-4952-2021-5(5)-284-296

Драч Ірина Іванівна доктор педагогічних наук, доцент, директор, Інститут вищої освіти НАПН України, вул. Бастіонна, 9, м. Київ, 01014, тел.: (044) 286-68-04, e-mail: drach_i@ukr.net, https://orcid.org/0000-0001-7501-4122

Слободянюк Олена Михайлівна кандидат педагогічних наук, методист навчально-методичного відділу, Вінницький національний технічний університет, Хмельницьке шосе, 95, м. Вінниця, 21021, тел.: (0432) 65-19-03, e-mail: lenaslobodianuk1970@gmail.com, https://orcid.org/0000-0002-1927-3362

\title{
СИСТЕМА ЗАБЕЗПЕЧЕННЯ АКАДЕМІЧНОЇ ДОБРОЧЕСНОСТІ В ВИЩІЙ ОСВІТІ ВЕЛИКОЇ БРИТАНІЇ: ОСОБЛИВОСТІ ЗАПРОВАДЖЕННЯ ТА ПІДТРИМКИ
}

Анотація. Приєднання України до Болонського процесу та входження до Європейського простору вищої освіти зумовлює посилення інституційної спроможності вітчизняних закладів вищої освіти, що передбачає, зокрема, підвищення якості освіти. Це, в свою чергу, актуалізує питання академічної доброчесності в освітньому середовищі. Академічна доброчесність передбачає впровадження інституційної політики щодо створення середовища, в якому дотримуються етичних стандартів при викладанні, навчанні, виконанні досліджень. У статті здійснено аналіз досвіду Великої Британії щодо забезпечення академічної доброчесності, визначено особливості імплементації політики та процедур. Встановлено, що в закладах вищої освіти Великої Британії забезпечення академічної доброчесності є одним з основних напрямів інституційних політик; дотримання принципів, норм, правил в освітньому процесі є обов'язковим для членів університетської спільноти. В британській закладах вищої освіти інституційні політики щодо академічної доброчесності $\epsilon$ чітко визначеними, відкритими і прозорими, з акцентом на забезпеченні надійності, конфіденційності і справедливості процесу розгляду звинувачень у неправомірній поведінці при навчанні; спрямованими на запобігання та забезпечення широких можливостей для навчання компетентностей 3 академічного письма, програм вдосконалення викладання; передбачають систематичний моніторинг стану дотримання принципів доброчесності в університеті. Проведений аналіз особливостей забезпечення політик академічної доброчесності університетів Великої Британії дали можливість запропонувати рекомендації для вітчизняних закладів вищої освіти щодо удосконалення інституційних політик.

Ключові слова: вища освіта Великої Британії, академічна доброчесність, політика та процедури забезпечення академічної доброчесності. 
Drach Iryna Ivanivna Doctor of Pedagogical Sciences, Associate Professor, Director, Institute of Higher Education of the National Academy of Pedagogical Sciences of Ukraine, Bastionna St., 9, Kyiv, 01014, tel.: (044) 286-68-04, e-mail: drach_i@ukr.net, https://orcid.org/0000-0001-7501-4122

Slobodianiuk Olena Mykhailivna Candidate of Pedagogical Sciences, Methodist of the Educational and Methodical Department, Vinnytsia National Technical University, Khmelnytske Shosse, 95, Vinnytsia, 21021, tel.: (0432) 65-19-03, e-mail: lenaslobodianuk1970@gmail.com, https://orcid.org/0000-0002-1927-3362

\section{ACADEMIC INTEGRITY SYSTEM IN GREAT BRITAIN HIGHER EDUCATION: FEATURES OF IMPLEMENTATION AND SUPPORT}

Abstract. Ukraine's accession to the Bologna Process and accession to the European Higher Education Area presupposes strengthening the institutional capacity of domestic higher education institutions, which includes, in particular, improving the quality of education. This, in turn, raises the issue of academic integrity in the educational environment. Academic integrity involves the implementation of institutional policies to create an environment in which ethical standards are adhered to in teaching, learning, and research. The article analyzes the experience of the United Kingdom in ensuring academic integrity, identifies the features of the implementation of policies and procedures. It has been established that ensuring academic integrity is one of the main directions of institutional policies in British higher education institutions; adherence to the principles, norms, rules in the educational process is mandatory for members of the university community. In British higher education institutions, institutional policies for academic integrity are clearly defined, open and transparent, with an emphasis on ensuring the reliability, confidentiality and fairness of the process of dealing with allegations of misconduct; aimed at preventing and providing ample opportunities for learning competencies in academic writing, teaching improvement programs; provide for systematic monitoring of compliance with the principles of integrity in the university. The analysis of the peculiarities of ensuring the policies of academic integrity of universities in the UK provided an opportunity to offer recommendations for domestic higher education institutions to improve institutional policies.

Keywords: higher education in Great Britain, academic integrity, policies and procedures for ensuring academic integrity.

Постановка проблеми. Зобов'язання перед європейською освітньою спільнотою (приєднання України до Болонського процесу та входження до Європейського простору вищої освіти та Європейського дослідницького простору), потреба українського ринку праці в високоосвічених компетентних фахівцях із сформованим соціогуманітарним світоглядом потребує системного 
Журнал«Герспективитаінновації наукиљ

(Серія «Гедагогіка», Серія«Гцихологія», Серія«Медицина»

№5(5) 2021

підходу до питання якості вищої освіти та іiі ціннісної складової, а саме академічної доброчесності.

У процесі модернізації вітчизняної вищої освіти акцентування уваги на необхідності формування політики та механізмів академічної доброчесності в університетському середовищі стало однією 3 ключових тенденцій, про що свідчать положення Закону України «Про вищу освіту» [1], Закону України «Про освіту» [2], Закону України «Про наукову та науково-технічну діяльність» [3] та інших документів.

Водночас на сьогодні спостерігається криза академічної доброчесності в Україні, яку спричинили фактори, визначені та уточнені в розширеному глосарії термінів та понять ст. 42 «Академічна доброчесність» Закону України «Про освіту» (від 5 вересня 2017 р.), зокрема загальна криза суспільства, про що свідчать численні порушення законодавства і етичних норм; неготовність вітчизняної наукових досліджень відповідати потребам суспільства, економіки та ринку праці; рівень фінансуванням закладів вищої освіти та науки, що не відповідає сучасним потребам галузі; неузгодженість законодавчо встановлених вимог і процедур оцінювання наукових та навчальних робіт на предмет наявності академічного плагіату, фабрикації, фальсифікації та інших порушень академічної доброчесності; внутрішня демотивація викладачів i науковців до дотримання принципів академічної доброчесності в умовах низьких зарплат та ін. [4]. Пандемія COVID-2019, перехід освітніх систем до змішаної форми навчання студентів посилив тенденцію щодо підвищення чисельності порушень правил, норм, принципів академічної доброчесності, що, вочевидь, стане причиною зниження якості освіті.

Кризова ситуація в вітчизняній освіті потребує швидких політикоправових, соціальних, організаційно-педагогічних, управлінських рішень на всіх рівнях (національному, інституційному). Приклад країн, що демонструють високий рівень освітніх послуг та результатів навчання студентів, свідченням чого $є$ їх розташування у першій десятці в міжнародних освітніх рейтингах, слугує орієнтиром для подальших кроків протидії таким порушенням академічної доброчесності, як обман, фальсифікація, фабрикація, шахраювання, плагіат та ін. Місце освітнього лідера європейської вищої освіти традиційно займає Велика Британія. Для визначення стратегії 3 подолання кризи академічної доброчесності в Україні актуально здійснити аналіз особливостей розвитку академічної доброчесності в системі вищої освіти Великої Британії як однієї з країн-світових лідерів вищої освіти.

Аналіз останніх досліджень і публікацій. Аналіз наукових праць дослідників та рекомендацій фахових експертів 3 проблем стану вищої освіти Великої Британії на сучасному етапі та розвитку академічної доброчесності $\epsilon$ передумовою для орієнтирів вітчизняної системи вищої освіти для подолання кризи академічних етичних стандартів. Серед переліку опрацьованих публікацій ми виділяємо: Е. Паскарелла та П. Терензіні (у контексті вивчення цінностей студентства) [5], Е. Колбі, Т. Ерліх, Е. Бьюмонт (у контексті 
особистої, соціальної відповідальності) [6], М. Біті, Д. Хенрі (у контексті формування моральних якостей [7], Е. Данн, Дж. Хатчисон, Е. Салліс (у контексті проблеми якості вищої освіти) [8; 9]. Системно та послідовно (на державному та інституційному рівнях) працюють над ініціативами та концептуальними підходами для вирішення складних питань, пов'язаних is порушеннями студентами академічної доброчесності Ф. Дагган, П. Бауган $[10 ; 11]$.

Мета статті полягає у виявленні особливостей забезпечення академічної доброчесності в вищій освіті Великої Британії.

Виклад основного матеріалу. Стрімкого розвитку на європейському рівні питання академічної доброчесності набуло завдяки активним зусиллям широкого кола професійних, економічних, політичних, культурно освітніх наднаціональних організацій, передусім таких, як Інститут неперервної освіти ЮНЕСКО (UNESCO Institute for Lifelong Learning), Свропейський Парламент та Рада ЄC (European Parliament and Council of the EU), Рада Європейського соціально-економічного комітету (the Council of the European economic and social Committee), Свропейська Асоціація Університетів (European University Association - EUA). В попередніх публікаціях ми вже відзначили роль окреслених організацій в накреслені підходів до побудови системи забезпечення академічної доброчесності в системі вищої освіти країн-учасниць Болонського процесу $[12 ; 13]$. Відзначимо, що документи наднаціональних політичних, економічних, професійних, культурно-освітніх організацій виступають підгрунтям для розроблення політико-правових засад формування політики щодо академічної доброчесності в закладах вищої освіти на національному рівні.

Визначимо документи, у яких відображено стратегію розвитку, методичне та технологічне забезпечення політики академічної доброчесності в університетах Великої Британії.

Провідну роль в формуванні ефективних політик академічної доброчесності в університетах Сполученого Королівства відіграє Агенція із забезпечення якості вищої освіти (англ. The Quality Assurance Agency for Higher Education, QAA), незалежний орган, який контролює кваліфікаційні стандарти вищої освіти. Діяльність QAA сприяє покращенню навчального досвіду студентів, незалежно від того, навчаються вони в університеті або коледжі, в межах кордонів чи за кордоном - за умов, що їх програма навчання передбачає здобуття британського диплому про вищу освіту. QAA, як незалежний орган, відіграє вирішальну роль щодо забезпечення якості та стандартів вищої освіти та високих стандартів та «працює 3 галузевими агентствами, урядовими відомствами, регулюючими органами, політиками і вченими, що володіють досвідом в сфері академічних порушень, для захисту академічної доброчесності та запобігання обману і шахрайства» [14].

Кодекс якості вищої освіти Великої Британії чітко передбачає, що диплом про вищу освіту можна присвоювати лише тоді, коли «досягнуті як порогові стандарти - мінімально допустимий рівень досягнень, так і власні академічні 
стандарти закладу, що присуджує освітній рівень, i коли досягнення запланованих результатів навчання було продемонстровано через процеси оцінки, які є справедливими, дійсними та надійними» [15 ].

Оскільки академічна доброчесність є ефективним інструментом збереження високих показників якості вищої освіти, питання їі забезпечення $\epsilon$ актуальним. 3 початком 2000-их рр. в наукових працях засвідчені негативні тенденції в вищій освіті Великої Британії, пов'язані з поширенням доступності інтернет-послуг [16; 17].

В 2016 р. QAA опублікувала власний звіт-занепокоєння. В звіті фіксується збільшувана загроза (для вищої освіти у Великій Британії) від послуг із написання письмових робіт на замовлення або «конвейерів письмових есе» [18]. Використання замовлених письмових робіт (або «обман за контрактом») $\epsilon$ специфічним типом плагіату: студент наймає третю сторону для виконання свого завдання за певну оплату, а потім подає таку роботу як свою власну. Проблеми неправомірної поведінки (обман, шахрайство, фальсифікація, плагіат та ін.), кваліфіковано як суспільну загрозу. До ii розв'язання представники QАA підключили професійні, статутні та регулятивні органи, 3 метою вироблення загального розуміння наслідків використання недоброчесних практик. Представники агентства виступили авторами ініціатив, а саме розробки Хартії академічної доброчесності (англ. Academic Integrity Charter) [19] та створення Консультативної групи 3 академічної доброчесності (англ. the Academic Integrity Advisory Group) [20], 3 метою протидії порушенням академічним етичним стандартам.

Хартія академічної доброчесності декларує зобов'язання всього сектору вищої освіти Великобританії сприяти академічній доброчесності та вирішувати проблеми, пов'язані з академічною поведінкою. В тексті підкреслено, що мета Хартії - створити методичну та методологічну основу, керуючись якою університети формуватимуть власну політику та практику академічної доброчесності, щоб гарантувати, що рівень якості освіти відповідає високим стандартам. В свою чергу, Консультативна група, створена в рамках QAA, надаватиме експертні поради та висновки від імені сектору щодо заходів, розробки та впровадження політики академічної доброчесності та запобігання ii порушень [20]. До складу групи входять представники провідних університетів, QАA, антиплагіатної програми Turnitin, Комітету з об'єднаних інформаційних систем (Joint Information Systems Committee, JISC), Палати лордів (лорд Сторі) та інших урядових відомств, регулюючих органів.

Врахувавши основні мету та завдання Кодексу якості вищої освіти Великої Британії (англ.UK Quality Code for Higher Education) [21], використовуючи поради та рекомендації щодо боротьби 3 шахрайством, розробленого JISC, в тексті Хартії сформульовано сім принципів забезпечення академічної доброчесності: відповідальності (кожна академічна спільнота несе відповідальність за запровадження та посилення академічної доброчесності), системності та цілісності (вся спільнота залучена до просування цінностей 
академічної доброчесності, а система іï забезпечення передбачає як заходи запобігання неправомірної поведінки, так і принцип невідворотності покарання за скоєне), залучення та розширення можливостей студентства, персоналу, викладацького складу, шляхом використання передових сучасних практик навчання і викладання); послідовності і ефективності політик та процесів та інституційної організаційної автономності [19].

Проаналізовані принципи $є$ основою для побудови ефективної та послідовної політики та механізмів забезпечення академічної доброчесності в університетах Великої Британії. Сформульовані принципи засвідчують, що академічну доброчесність розглянуто як багато компонентне та багаторівневе поняття. Одним із визначальних принципів імплементації цінностей академічної доброчесності та особливістю іiі забезпечення в університетах $\epsilon$ розподілена відповідальність на усіх рівнях сектору вищої освіти: від національного рівня, структурних підрозділів в університетах до кожного студента, викладача, представника персоналу. Забезпечення академічної доброчесності - тривалий та постійний процес, що передбачає одночасне використання ресурсів (структурних, технічних, освітніх), з метою запобігання порушенням, надання знань студентам про інструменти ефективного навчання та удосконалення процесу викладання. В системі вищої освіти Великої Британії актуалізовано питання широкого залучення учасників освітнього процесу до процесів, процедур, заходів сприяння академічній доброчесності. Відзначимо, що порушення норм, правил, принципів, визначених політикою закладу, призводить до невідворотності покарання, а сприяння, пропагування цінностей та зразкове виконання обов'язків є приводом для відзначення. Таким чином, цілісне навчання, розподілена відповідальність та застосування лідерського підходу є тими особливостями, які формують ефективну політику забезпечення академічної доброчесності в країні, що займає лідируючі позиції в світових освітніх рейтингах.

В серпні 2016 р. оприлюднено звіт Plagiarism in Higher Education. Custom essay writing services: an exploration and next steps for the UK higher education sector щодо «custom essay writing services» [18], в якому наголошено, що загроза від «custom essay writing services» потребує не точкових рішень, а системного підходу. Експертами AAQ критично оцінені ризики для якості вищої освіти Великої Британії, іï репутації та запропоновано дві редакції Contracting to Cheatin Higher Education. How to Address Essay Millsand Contract Cheating. В колективних працях досліджено та запропоновано рекомендації щодо протидії порушення академічної доброчесності. Гнучкість та адаптивність системи вищої освіти дозволили швидко напрацювати рекомендації та впровадити їх в освітній процес [22].

Детально опрацьовані обидві редакції Contracting to Cheat in Higher Education. How to Address Essay Mills and Contract Cheating (2017 p.) [.23], Contracting to Cheat in Higher Education. How to Address Essay Mills and Contract Cheating (2020) [24] дозволили презентувати концептуальні положення, які 
вважаємо особливо цінними для нашого дослідження та відзначають специфіку освітнього процесу в умовах пандемії:

1. Освіта та підтримка. Умови пандемії, змішані форми навчання потребують додаткової уваги до організації освітнього процесу. Критично важливим для розвитку студентів $€$ запровадження широкого доступу до послуг персонального репетиторства та академічного наставництва, що забезпечить високі академічні результати $[24$, р. 15].

Запропоновано внести зміни в діяльність викладацького складу. Авторським колективом Contracting to Cheat in Higher Education. How to Address Essay Mills and Contract Cheating (2020) рекомендовано: по-перше, включити зобов'язання захищати цінності академічної доброчесності до посадових інструкцій персоналу та, по-друге, визначити відповідальну особу та створити єдиний ресурсний центр, що координуватиме всі процеси, пов'язані 3 забезпеченням політики академічної доброчесності в університеті.

2. Запобігання. В умовах пандемії, на думку авторів публікацій, для підтримки інституційної спроможності університетів, по-перше, принципово переосмислити ефективність видів, форм викладання навчальних курсів, їх структури та змісту; по-друге, визначити інструменти (процеси, процедури, заходи), які зменшать кількість неправомірної поведінки в умовах пандемії [24, p.22]. Стратегічно важливо зменшити можливості для порушень та посилити спроможність інституційних політик, процесів, процедур до їх запобігання і виявлення.

Особливої уваги в умовах дистанційної чи змішаної форм навчання заслуговує оцінювання: «Належний дизайн оцінки - це один із набору підходів, який може допомогти зменшити кількість випадків шахрайства», стверджують автори рекомендацій [24, р. 21]. Актуальним залишається питання розробки та використання різноманітних методів оцінювання: автентичне, контекстуально-конкретне, персоналізоване, експертна оцінка, відео презентація.

3. Виявлення. В умовах змішаної форми навчання зростає кількість студентів, які користуються послугами онлайн-репетиторства під час складання іспитів. Компанії, що займаються онлайн-навчанням, надають законні послуги при умові, що попереджають студентів не подавати надані матеріали викладачам як власну роботу. Контроль за діяльністю сайтів 3 онлайн-репетиторства потребуватиме додаткових ресурсів університету.

4. Нормативні акти/політики: стратегія, прозорість, послідовність. Системний підхід до забезпечення політики академічної доброчесності передбачає: цілісну послідовну стратегію, яка підтримує та сприяє академічній доброчесності, зменшуючи ймовірність того, що студенти вдаватимуться до академічних проступків; позитивний інституційний дух, включаючи педагогічні практики, що вимагають складних видів діяльності, критичного мислення та наукових результатів.

Принцип прозорості стосується детальних вказівок уповноважених 
осіб/структур щодо розгляду випадків порушень академічної доброчесності: розслідування, рішення, санкції, пом'якшувальні обставини, результати та апеляції [24, p.31]. Процес розгляду справи передбачає прозорість процедур, а рішення - чіткості формулювання. Результати розслідування потребують обговорення, а не простої констатації на інформаційному сайті закладу.

Послідовність регулювання передбачає:

- загальний та послідовний підхід формування політики академічної доброчесності, підкріплений академічними нормативними актами;

- наявність відповідних ресурсів (в ідеалі - зі спеціальною посадою персоналу) та потужною підтримкою керівництва університету, лідерства в питання зразкових моделей поведінки та заохочення всіх учасників освітнього процесу до просування цінностей академічної доброчесності.

Заслуговує на окрему увагу питання процедур, справедливих та прозорих. Виваженість рішень відповідальних осіб/структур університету, що забезпечують реалізацію політик та висновки яких не викликають сумнівів один із визначальних інструментів сталості побудованої системи забезпечення академічної доброчесності. «Основи належної практики: Дисциплінарні процедури» (англ. The good practice framework: Disciplinary procedures (2018) [25] - документ, який уклали на базі найкращих практик в Офісі незалежного судді у вищій освіті (англ. Office of the Independent Adjudicator for Higher Education) та який містить рекомендації для розробників дисциплінарних процедур та розгляду окремих справ. Документ сприяє запровадженню стандартного підходу до:

- класифікації видів академічних порушень (плагіат, самоплагіат, здійснення копії роботи іншого студента без їх дозволу, фальсифікація даних, доказів чи експериментальних результатів; змова, обман за контрактом, обман на іспитах (підміна особи на іспиті, несанкціоноване володіння матеріалом, використання допоміжних пристроїв під час іспиту), порушення дослідницької та етичної політики),

- узгодження етапів розгляду справ (етап попереднього слідства, офіційний етап та апеляція) [25].

Документ містить припис про обов'язковість процедур, а саме: усі випадки про підозри неправомірних дій зареєстровані та розслідувані, відповідальна особа/структура не має права розглядати справу самостійно, представники студентських організацій повинні бути обізнані з процедурами розгляду справ про порушення академічної доброчесності.

Розроблення та широке використання стандартизованих механізмів забезпечення дотримання академічних етичних норм (заходів, процесів, процедур, діяльність відповідальних структур) $є$ невід'ємною складовою ефективного імплементації політики академічної доброчесності та тенденцією в вищій освіті Великої Британії.

Отже, усвідомлення зв'язку між якістю освіти та академічною доброчесністю як іiї ціннісною складовою, а також системний аналіз підходів та 
принципів забезпечення, дослідження та запровадження найкращих позитивних практик, реалізованих в університетах Великої Британії, спільна наукова діяльність QАA 3 дослідниками провідних наукових та освітніх установ - все це дозволило сформулювати рекомендації, що сприяють просуванню ідеям навчання та викладання на ціннісних засадах. Дослідження засвідчило, що процес забезпечення академічної доброчесності є регульованим та охоплює: освіту та підтримку щодо питань академічної доброчесності усіх учасників освітнього процесу; обов'язкове виявлення та звітування про випадки порушень; процес розслідування, який передбачає системність і послідовність процедур та настання наслідків (як результату розслідування). Рішення, прийняті централізовано (на національному рівні), потребують реалізації на різних рівнях, а саме: на рівні факультетів, кафедр, навчальних груп та ін.

Висновки. Однією з ключових тенденцій удосконалення системи вищої освіти Великої Британії $\epsilon$ акцентування уваги на необхідності формування культури академічної доброчесності. Аналіз наукових праць зарубіжних та українських дослідників, офіційних документів, що регулюють етичні академічні стандарти в освітньому середовищі, підтвердив актуальність проблеми дотримання принципів доброчесності в навчанні, викладанні, дослідженнях для сучасної вищої освіти. Дослідження політики забезпечення академічної доброчесності у вищій освіті Великої Британії дозволив виокремити їі особливості:

- прихильність до дотримання академічної доброчесності продемонстрована через інституційні цінності, задекларовані в політиці університету; політики та процедури забезпечення академічної доброчесності узгоджені, послідовні та визнані усіма учасниками освітнього процесу;

- інституційні політики щодо академічної доброчесності $\epsilon$ чітко визначеними, відкритими і прозорими, з акцентом на забезпеченні надійності, конфіденційності i справедливості процесу розгляду звинувачень у неправомірній поведінці при навчанні; спрямованими на запобігання та забезпечення широких можливостей для навчання компетентностей 3 академічного письма, програм вдосконалення викладання; передбачають систематичний моніторинг стану дотримання принципів доброчесності в університеті.

Виокремлені особливості визначають ефективність політики забезпечення академічної доброчесності в університетах Великої Британії, що дозволяє нам запропонувати наступні рекомендації закладам вищої освіти України:

- акцентувати увагу на тому, що ціннісною складовою корпоративної культури університету мають стати принципи академічної доброчесності (справедливість, довіра, повага, чесність, відповідальність, мужність), які забезпечують високі моральні стандарти та є гарантом якісної освіти в закладах вищої освіти. Ключові цінності, переконання та норми поведінки, що сприймаються як обов'язкові для осмислення та прийняття усіма членами 
університетської спільноти, створюють відчуття єдності та відданості спільній місії підготовки висококваліфікованих фахівців;

- враховувати, що важливою умовою запровадження принципів академічної доброчесності є залученість всіх учасників освітнього процесу, що потребує розбудови нових механізмів взаємодії в трикутнику студентвикладач-адміністрація університету та пріоритетності горизонтальних зв'язків.

\section{Лimepamypa:}

1. Закон України «Про вищу освіту» : чинне законодавство : (офіц. текст). К. : ПАЛИВОДА А. В., 2014. 100 с.

2. Закон України «Про освіту» : станом на 2 жовтня 2021 р. / Верховна Рада України. URL: https://zakon.rada.gov.ua/laws/show/2145-19\#Tехt (дата звернення: 14. 12. 2021).

3. Закон України «Про наукову і науково-технічну діяльність» : станом на 26 листопада 2015 р. / Верховна Рада України. URL: https://zakon.rada.gov.ua/laws/show/84819\#Техt (дата звернення: 14.12.2021).

4. Розширений глосарій термінів та понять ст. 42 «Академічна доброчесність» Закону України «Про освіту» : лист МОН України до керівників закладів вищої освіти від 23 жовтня 2018 p. №. 1/9-650. URL: https://mon.gov.ua/storage/app/media/vishchaosvita/2018/10/25/glyusariy.pdf (дата звернення: 14.12.2021).

5. Pascarella E., Terenzini P. How College Affects Students: Ten Directions for Future Research. Academe, Vol. 78, No. 4. 1992. Pp. 44-47. URL: http://www.jstor.org/stable/40250363 (дата звернення: 14.12.2021).

6. Colby A., Ehrlich T., Beaumont E., Stephens J. Educating Citizens: Preparing America's Undergraduates for Lives of Moral and Civic Responsibility. San Francisco CA: Jossey-Bass, 2003. $332 \mathrm{p}$.

7. Henry D., Beaty M. The Schooled Heart: Moral Formation in American Higher Education (pp. 73-102). Waco TX: Baylor University Press. 2007. 230 p.

8. Dunn K., Mulvenon S. (2009). A Critical Review of Research on Formative Assessments: The Limited Scientific Evidence of the Impact of Formative Assessments in Education. Practical Assessment Research \& Evaluation. No. 14 (7). 2009. URL: https://scholarworks.umass.edu/pare/ vol14/iss $1 / 7$ (дата звернення: 14.12.2021).

9. Kay J., Dunne E., Hutchinson J. Rethinking the values of higher education - students as change agents? The Quality Assurance Agency for Higher Education (QAA): Southgate House, 2010. 10.p. URL: http://dera.ioe.ac.uk/id/eprint/1193 (дата звернення: 14.12.2021).

10 Duggan, F. (ed.) (2006a) Special Issue. Plagiarism: Prevention, Practice and Policy. Assessment \& Evaluation in Higher Education. No. 31 (2). 2006. Pp. 151-154.

11 Baughan, P. (2010). StudyWell: Encouraging positive study skills by students and staff. Supporting academic integrity Approaches and resources for higher education. Pp. 39-41. URL: https://openaccess.city.ac.uk/id/eprint/14813/ (дата звернення: 14.12.2021).

12. Слободянюк О. М. Забезпечення дотримання принципів академічної доброчесності у контексті Болонського процесу // Педагогіка формування творчої особистості у вищій і загальноосвітній школах : зб. наук. пр. / [редкол. : А.В. Сущенко (голов. ред.) та ін.]. 2019. Вип. 65. C.130-134.

13. Драч I. I. Досвід управління дослідницькою діяльністю в університетах Сполученого Королівства: філософсько-аналітичний підхід // Університети і лідерство. №1 (5). 2018. C. 13-25.

14. The Quality Assurance Agency for Higher Education. URL: https://www.qaa.ac.uk/ about-us (дата звернення: 14.12.2021).

15. UK Quality Code for Higher Education. URL: www.qaa.ac.uk/assuring-standards-andquality/the-quality-code (дата звернення: 14.12.2021). 
16. Glendinning, I. Evaluation of Policies for Academic Integrity in Higher Education: An International Perspective. Unpublished PhD Thesis. Coventry: Coventry University. URL: http://curve.coventry.ac.uk/open/items/6200b505-ea88-49b4-bc8c-b56cdb38a5e9/1/ (дата звернення: 14.12.2021).

17. Carroll J. 'Handling Student Plagiarism: Moving to Mainstream / Brookes e-Journal of Learning \& Teaching. Vol. 1 (2). 2005. URL: file:///C:/Users/Helen/Downloads/Handling student plagiarism.pdf (дата звернення: 14.12.2021).

18. Plagiarism in Higher Education. Custom essay writing services: an exploration and next steps for the UK higher education sector. URL:https://www.qaa.ac.uk/docs/qaa/qualitycode/plagiarism-in-higher-education-2016.pdf?sfvrsn=308cfe81_4 (дата звернення: 14.12.2021).

19. The Quality Assurance Agency for Higher Education: Academic Integrity Charter. URL: https://www.qaa.ac.uk/membership/highlights-from-last-years-membershipactivities/academic-integrity/academic-integrity-charter (дата звернення: 14.12.2021).

20. The Quality Assurance Agency for Higher Education: Academic Integrity Advisory Group. URL: https://bitly.su/tw2dO6c (дата звернення: 14.12.2021).

21. The Quality Assurance Agency for Higher Education: The revised UK Quality Code for Higher Education. URL: https://www.qaa.ac.uk/quality-code (дата звернення: 14.12.2021).

22. Слободянюк О. М. Система забезпечення академічної доброчесності в університетах Великої Британії: від розробки політики до практики втілення // Актуальні питання гуманітарних наук : міжвузівський зб. наук. праць молодих вчених Дрогобицького державного педагогічного ун-ту. Вип. 40. 2020. С. 193-198.

23. Contracting to Cheat in Higher Education. How to Address Essay Mills and Contract Cheating (1st. Edition.). 2017. URL: https://www.qaa.ac.uk/docs/qaa/quality-code/contracting-tocheat-in-higher-education.pdf (дата звернення: 14.12.2021).

24 Contracting to Cheat in Higher Education. How to Address Essay Mills and Contract Cheating (2nd Edition.). 2020. URL: https://www.qaa.ac.uk/docs/qaa/guidance/contracting-tocheat-in-higher-education-2nd-edition.pdf (дата звернення: 14.12.2021).

25. The good practice framework: Disciplinary procedures. URL: https://www.oiahe.org.uk/ media/2045/good-practice-framework-disciplinary-procedures-section.pdf (дата звернення: 14.12.2021).

\section{References:}

1. Zakon Ukrainy «Pro vyshchu osvitu» (2014). [Law of Ukraine «On higher education»]. Retrieved from: https://bit.ly/3yZLkH5 [in Ukrainian].

2. Zakon Ukrainy «Pro osvitu» (2017). [Law of Ukraine «On education»]. Retrieved from: http://zakon3.rada.gov.ua/laws/show/2145-19 (last accessed: 14. 12.2021) [in Ukrainian].

3. Zakon Ukrainy «Pro naukovu i naukovo-tekhnichnu diialnist»: stanom na 26 lystopada 2015 r. / Verkhovna Rada Ukrainy. [Law of Ukraine «On scientific and scientific-technical activities»: as of November 26, 2015 / The Verkhovna Rada of Ukraine]. URL: https://zakon.rada.gov.ua/laws/show/848-19\#Text (last accessed: 14. 12.2021) [in Ukrainian].

4. Rozshyrenyi hlosarii terminiv ta poniat st. 42 «Akademichna dobrochesnist» Zakonu Ukrainy «Pro osvitu» : lyst MON Ukrainy do kerivnykiv zakladiv vyshchoi osvity vid 23 zhovtnia 2018 r. №. 1/9650 [Extended glossary of terms and concepts of Art. 42 «Academic Integrity» of the Law of Ukraine «On Education»: a letter from the Ministry of Education and Science of Ukraine to the heads of higher education institutions dated October 23, 2018 №. 1 / 9-65 ]. URL: https://mon.gov.ua/storage/ app/media/vishcha-osvita/2018/10/25/glyusariy.pdf (last accessed: 14. 12.2021) [in Ukrainian].

5. Pascarella E., Terenzini P. (1992). How College Affects Students: Ten Directions for Future Research. Academe, Vol. 78, No. 4. Pp. 44-47 URL: http://www.jstor.org/stable/40250363 (last accessed: 14. 12.2021).

6. Colby A., Ehrlich T., Beaumont E., Stephens J. (2003). Educating Citizens: Preparing America's Undergraduates for Lives of Moral and Civic Responsibility. San Francisco CA: Jossey-Bass. 332 p. 
7. Henry D., Beaty M. (2007). The Schooled Heart: Moral Formation in American Higher Education (pp. 73-102). Waco TX: Baylor University Press. 230 p.

8. Dunn K., Mulvenon S. (2009). A Critical Review of Research on Formative Assessments: The Limited Scientific Evidence of the Impact of Formative Assessments in Education. Practical Assessment Research \& Evaluation. No. 14 (7). URL: :https://scholarworks.umass.edu/pare/vol14/iss1/7 (last accessed: 14. 12.2021).

9. Kay J., Dunne E., Hutchinson J. (2010). Rethinking the values of higher education students as change agents? The Quality Assurance Agency for Higher Education (QAA): Southgate House, 10.p. URL: http://dera.ioe.ac.uk/id/eprint/1193 (last accessed: 14. 12.2021).

10 Duggan, F. (ed.) (2006) Special Issue. Plagiarism: Prevention, Practice and Policy. Assessment \& Evaluation in Higher Education. No. 31 (2). Pp. 151-154.

11 Baughan, P. (2010). StudyWell: Encouraging positive study skills by students and staff. Supporting academic integrity Approaches and resources for higher education, pp. 39-41. URL: https://openaccess.city.ac.uk/id/eprint/14813/ (last accessed: 14. 12.2021).

12. Slobodianiuk O. M. (2019). Zabezpechennia dotrymannia pryntsypiv akademichnoi dobrochesnosti u konteksti Bolonskoho protsesu // Pedahohika formuvannia tvorchoi osobystosti u vyshchii i zahalnoosvitnii shkolakh : zb. nauk. pr. / [redkol. : A.V. Sushchenko (holov. red.) ta in.]. [Ensuring adherence to the principles of academic integrity in the context of the Bologna Process]. Pedahohika formuvannia tvorchoi osobystosti u vyshchii i zahalnoosvitnii shkolakh : zb. nauk. pr. / [redkol. : A.V. Sushchenko (holov. red.) ta in.]. Vol. 65, Pp. 130-134 [in Ukrainian].

13. Drach I. (2018). Dosvid upravliinnia doslidnytsckoiu diialnistiu uvuniversyteta h Velukoi Brutanii: filosofsko-analitucnuj pidhid [Experience of Management of Research Activities at the University of the United Kingdom]. Universitet i liderstvo, No. 5, Pp. 13-25. URL: http://elitejournal.org/ (last accessed: 14.12.2021) [in Ukrainian].

14. The Quality Assurance Agency for Higher Education. URL: https://www.qaa.ac.uk/ about-us (last accessed: 14.12.2021).

15. UK Quality Code for Higher Education. URL: www.qaa.ac.uk/assuring-standards-andquality/the-quality-code(last accessed: 14.12.2021) (last accessed: 14.12.2021).

16. Glendinning I. (2016). Evaluation of Policies for Academic Integrity in Higher Education: An International Perspective. Unpublished PhD Thesis. Coventry: Coventry University. URL: http://curve.coventry.ac.uk/open/items/6200b505-ea88-49b4-bc8c-b56cdb38a5e9/1/ (last accessed: 14.12.2021).

17. Carroll J. (2005). Handling Student Plagiarism: Moving to Mainstream / Brookes e-Journal of Learning \& Teaching. Vol. 1 (2). URL: file:///C:/Users/Helen/Downloads/Handling_student_ plagiarism.pdf (last accessed: 14.12.2021).

18. Plagiarism in Higher Education. Custom essay writing services: an exploration and next steps for the UK higher education sector. URL:https://www.qaa.ac.uk/docs/qaa/qualitycode/plagiarism-in-higher-education-2016.pdf?sfvrsn=308cfe81_4 (last accessed: 14.12.2021).

19. The Quality Assurance Agency for Higher Education: Academic Integrity Charter. URL: https://www.qaa.ac.uk/membership/highlights-from-last-years-membershipactivities/academic-integrity/academic-integrity-charter (last accessed: 14.12.2021).

20. The Quality Assurance Agency for Higher Education: Academic Integrity Advisory Group. URL: https://bitly.su/tw2dO6c (last accessed: 14.12.2021).

21. The Quality Assurance Agency for Higher Education: The revised UK Quality Code for Higher Education. URL: https://www.qaa.ac.uk/quality-code (last accessed: 14.12.2021).

22. Slobodianiuk O. M. (2020). Systema zabezpechennia akademichnoi dobrochesnosti v universytetakh Velykoi Brytanii: vid rozrobky polityky do praktyky vtilennia [The Academic Integrity System in UK Universities: From Policy Development to Implementation Practice]. Aktualni pytannia humanitarnykh nauk : mizhvuzivskyi zb. nauk. prats molodykh vchenykh Drohobytskoho derzhavnoho pedahohichnoho un-tu, Vol. 40, Pp. 193-198 [in Ukrainian]. 
23. Contracting to Cheat in Higher Education. How to Address Essay Mills and Contract Cheating (1st. Edition.). (2017). URL: https://www.qaa.ac.uk/docs/qaa/quality-code/contracting-tocheat-in-higher-education.pdf . (last accessed: 14.12.2021).

24 Contracting to Cheat in Higher Education. How to Address Essay Mills and Contract Cheating (2nd Edition.). (2020). URL: https://www.qaa.ac.uk/docs/qaa/guidance/contracting-tocheat-in-higher-education-2nd-edition.pdf (last accessed: 14.12.2021).

25. The good practice framework: Disciplinary procedures. URL: https://www.oiahe.org.uk/media/ 2045/good-practice-framework-disciplinary-procedures-section.pdf (last accessed: 14.12.2021). 